\title{
Neuropeptide co-expression in hypothalamic kisspeptin neurons of laboratory animals and the human
}

\author{
Katalin Skrapits ${ }^{1}$, Beáta Á. Borsay ${ }^{2}$, László Herczeg ${ }^{2}$, Philippe Ciofi ${ }^{3}$, Zsolt Liposits ${ }^{1,4}$ and \\ Erik Hrabovszky ${ }^{1 *}$ \\ 1 Laboratory of Endocrine Neurobiology, Institute of Experimental Medicine, Hungarian Academy of Sciences, Budapest, Hungary \\ ${ }^{2}$ Department of Forensic Medicine, Clinical Center, University of Debrecen, Debrecen, Hungary \\ ${ }^{3}$ Neurocentre Magendie, Institut National de la Santé et de la Recherche Médicale U862, Bordeaux, France \\ ${ }^{4}$ Department of Neuroscience, Faculty of Information Technology and Bionics, Pázmány Péter Catholic University, Budapest, Hungary
}

\section{Edited by:}

Hubert Vaudry, University of Rouen, France

\section{Reviewed by:}

Victor M. Navarro, Harvard Medical School, USA

Andrew Wolfe, Johns Hopkins

University, USA

Naomi Ellen Rance, University of

Arizona, USA

*Correspondence:

Erik Hrabovszky, Laboratory of

Endocrine Neurobiology, Institute of Experimental Medicine, Hungarian Academy of Sciences, 43 Szigony

St., Budapest 1083, Hungary

e-mail: hrabovszky.erik@koki.hu
Hypothalamic peptidergic neurons using kisspeptin (KP) and its co-transmitters for communication are critically involved in the regulation of mammalian reproduction and puberty. This article provides an overview of neuropeptides present in KP neurons, with a focus on the human species. Immunohistochemical studies reveal that large subsets of human KP neurons synthesize neurokinin B, as also shown in laboratory animals. In contrast, dynorphin described in KP neurons of rodents and sheep is found rarely in KP cells of human males and postmenopausal females. Similarly, galanin is detectable in mouse, but not human, KP cells, whereas substance $P_{1}$ cocaine- and amphetamine-regulated transcript and proenkephalin-derived opioids are expressed in varying subsets of KP neurons in humans, but not reported in ARC of other species. Human KP neurons do not contain neurotensin, cholecystokinin, proopiomelanocortin-derivatives, agouti-related protein, neuropeptide $Y$, somatostatin or tyrosine hydroxylase (dopamine). These data identify the possible co-transmitters of human KP cells. Neurochemical properties distinct from those of laboratory species indicate that humans use considerably different neurotransmitter mechanisms to regulate fertility.

Keywords: CART, dynorphin, hypothalamus, kisspeptin, neurokinin B, reproduction, substance $P$

\section{REPRODUCTIVE SIGNIFICANCE OF KP NEURONS IN MAMMALS}

Hypothalamic neurons synthesizing kisspeptin (KP) play a pivotal role in the central regulation of puberty and reproduction. Inactivating mutations of the genes encoding for $\mathrm{KP}$ (KISS1) (Topaloglu et al., 2012) or its G-protein-coupled receptor (KISS1R; previously called GPR-54) (De Roux et al., 2003; Seminara et al., 2003) cause hypogonadotropic hypogonadism in humans. Impaired fertility has also been observed in Kiss 1 (D'anglemont De Tassigny et al., 2007; Lapatto et al., 2007)and Kiss1r knock-out mice (Funes et al., 2003; Seminara et al., 2003) suggesting the highly conserved reproductive significance of KP/KISS1R-signaling in mammals. KP is a potent stimulator of adenohypophysial LH and FSH secretion (Navarro et al., $2005 \mathrm{a}, \mathrm{b})$. This action involves gonadotropin-releasing hormone (GnRH) and can be prevented with the GnRH receptor antagonist acyline (Gottsch et al., 2004; Shahab et al., 2005). The major effect of KP on GnRH-synthesizing neurons is direct. In various species, (i) KP-immunoreactive (IR) fibers establish appositions to GnRH neurons (Kinoshita et al., 2005; Clarkson and Herbison, 2006; Ramaswamy et al., 2008; Smith et al., 2008), (ii) GnRH cells express Kiss1r (Irwig et al., 2004; Han et al., 2005; Messager et al., 2005), (iii) GnRH neurons responds to KP with cFos expression (Irwig et al., 2004; Matsui et al., 2004) and depolarization (Han et al., 2005; Dumalska et al., 2008; Pielecka-Fortuna et al., 2008), (iv) the GnRH-specific Kiss1 $r^{-/-}$mice are infertile (Novaira et al., 2014) and (v) the infertile phenotype of global Kiss $1 r^{-/-}$mutant mice can be rescued via the selective reinsertion of Kiss $1 r$ into GnRH neurons (Kirilov et al., 2013).

\section{FUNCTIONAL SUBSETS OF KP NEURONS IN LABORATORY SPECIES AND THE HUMAN}

In a variety of mammals, two major populations of KPsynthesizing neurons exist in the anterior preoptic area and the arcuate nucleus (ARC), respectively (Lehman et al., 2010a). In rodents, the anterior preoptic cell group occurs as a periventricular continuum within the anterior periventricular (AVPV) and the periventricular preoptic (PVpo) nuclei (Clarkson and Herbison, 2006), together referred to as the KP neuron population of the rostral periventricular area of the third ventricle (RP3V) (Clarkson et al., 2008). Both KP cell populations are also detectable in the human, with the bulk of neurons in the infundibular (=arcuate) nucleus (Inf) (Rometo et al., 2007; Hrabovszky, 2013). KP neurons in the rodent RP3V and both KP cell groups in the human are sexually dimorphic, with higher cell number in females than in males (Clarkson and Herbison, 2006; Kauffman et al., 2007; Hrabovszky et al., 2010, 2011). Information accumulated in recent years indicate that both cell populations 
contain other neuropeptides and classic transmitters, in addition to KP. This review article discusses the available literature about these co-transmitters of KP neurons in laboratory species and humans, as also summarized in Figure 2.

\section{CO-TRANSMITTERS AND THEIR RECEPTORS IN KP NEURONS OF LABORATORY SPECIES KP NEURONS OF THE ANTERIOR PREOPTIC REGION}

$\mathrm{KP}$ cells in the RP3V of female rodents have been implicated in positive estrogen feedback to GnRH neurons (Adachi et al., 2007; Herbison, 2008; Robertson et al., 2009). Immunohistochemical (IHC) and in situ hybridization (ISH) studies revealed that KP neurons in the RP3V express other neuropeptides as well as classic neurotransmitters.

\section{Met-enkephalin (mENK)}

Neurons IR to the proenkephalin (pENK)-derived opioid mENK overlap with KP-IR cells of the RP3V. Porteous et al. reported that, in adult female mice, dual-phenotype $\mathrm{KP} / \mathrm{mENK}$ cells represent $28-38 \%$ of all KP-IR and $58-68 \%$ of all mENK-IR neurons in the AVPV and PVpo, respectively. These neurons give rise to duallabeled axon varicosities which project to the preoptic area, the anterior hypothalamus and the ARC (Porteous et al., 2011).

\section{Galanin}

Recent ISH and IHC studies have established that galanin is also present in a subset of KP neurons in the RP3V of the mouse (Porteous et al., 2011; Kallo et al., 2012). In estrogen-treated ovariectomized mice, galanin was detected in $87 \%$, and galanin mRNA in 38\%, of KP neurons (Kallo et al., 2012). A lower incidence of colocalization was reported by Porteous et al.; in their study dual-labeled cells represented 7\% of all KP-IR and $21 \%$ of all galanin-IR neurons both in the AVPV and PVpo of colchicine-pretreated female mice (Porteous et al., 2011).

\section{Tyrosine hydroxylase (dopamine)}

Tyrosine hydroxylase ( $\mathrm{TH})$ is a key and rate-limiting enzyme in catecholamine synthesis. Similarly to KP cells, TH-containing neurons in the RP3V are sexually differentiated in rodents (Kauffman et al., 2007; Clarkson and Herbison, 2011). In female rats, $20-50 \%$ of Kiss 1 mRNA-expressing cells in the $\mathrm{RP} 3 \mathrm{~V}$, depending on the hormonal status, express $\mathrm{TH}$ mRNA (Kauffman et al., 2007). In female mice, 50\% of KP cells contain $\mathrm{TH}$ immunoreactivity and vice versa, without noticeable variation between diestrus and proestrus. These KP/TH dualphenotype neurons were also proposed to serve as the major source of dopamine in the synaptic regulation of $\mathrm{GnRH}$ neurons (Clarkson and Herbison, 2011).

\section{GABA and glutamate}

Dual-label ISH studies have established that about $20 \%$ of KP neurons in the mouse AVPV also express the mRNA encoding the glutamatergic marker type-2 vesicular glutamate transporter (vGluT2), whereas the mRNA of the GABA-synthesizing enzyme glutamic acid decarboxylase (GAD-67) was expressed in 75\% of KP neurons (Cravo et al., 2011). These data indicate that AVPV $\mathrm{KP}$ neurons use amino acidergic, in addition to peptidergic and dopaminergic co-transmission.

\section{"KNDy" NEURONS IN THE ARC/Inf}

Unlike the preoptic cell population, KP neurons of the ARC cosynthesize KP, neurokinin B (NKB) and dynorphin (Dyn) in several species (Burke et al., 2006; Foradori et al., 2006; Goodman et al., 2007; Navarro et al., 2011a; Bartzen-Sprauer et al., 2014), forming the basis for the "KNDy neuron" terminology (Lehman et al., 2010b). It is only becoming recognized lately that KNDy neurons do not consist of a homogenous cell population in that co-expression of the three KNDy peptides is only partial (Cheng et al., 2010; Hrabovszky et al., 2010, 2011, 2012; Overgaard et al., 2014). Morphological and electrophysiological studies provided evidence that KNDy neurons communicate extensively with each other (Burke et al., 2006; Foradori et al., 2006; Goodman et al., 2007; Navarro et al., 2011a,b; De Croft et al., 2013; Ruka et al., 2013). This local communication via NKB/neurokinin 3 receptor (NK3R) and Dyn/K-opioid receptor (KOR) signaling was proposed to play a critical role in the generation of episodic GnRH/LH pulses (Navarro et al., 2009; Ohkura et al., 2009; Wakabayashi et al., 2010).

In addition to playing a putative role in the regulation of pulsatile GnRH/LH secretion, KNDy neurons have been implicated in negative sex steroid feedback action. Accordingly, neurotoxic ablation of KNDy neurons in rats prevented the rise in serum LH after ovariectomy (Mittelman-Smith et al., 2012). In some species like the sheep and primates, KNDy neurons might also be involved in positive estrogen feedback regulation. KP neurons in the ARC of ovariectomized ewes respond with cFos expression to estradiol treatment (Smith et al., 2009) and female rhesus monkeys with a disconnected mediobasal hypothalamus continue to respond to estrogen with LH and FSH surges (Krey et al., 1975; Plant et al., 1979). In contrast with the data from sheep, KP neurons in the preoptic area, but not the ARC, are activated during the positive estradiol feedback in goats (Matsuda et al., 2014).

Moreover, as reviewed by Rance et al., KP neurons in the $\mathrm{ARC} / \mathrm{Inf}$ are also involved in the control of thermoregulation and their dysfunction is likely to contribute to the generation of hot flushes during menopause (Rance et al., 2013).

KP neurons of the ARC co-contain other neuropeptides, neuropeptide receptors and classic neurotransmitters in different laboratory species, as discussed below.

\section{NKB and its receptor NK3R}

The high reproductive significance of $\mathrm{NKB}$, product of the human TAC3 and mouse Tac2 genes, has been recognized recently (Lasaga and Debeljuk, 2011). Mutations in the TAC3 or TACR3 genes encoding for $\mathrm{NKB}$ and its receptor $\mathrm{NK} 3 \mathrm{R}$, respectively, lead to hypogonadotropic hypogonadism and infertility in humans (Guran et al., 2009; Topaloglu et al., 2009). In laboratory species, large percentages of ARC/Inf KP neurons contain NKB or NK3R, although the reported colocalization patterns vary largely by species, sex and age (Burke et al., 2006; Goodman et al., 2007; Navarro et al., 2009, 2011a; Amstalden et al., 2010; Cheng et al., 2010; Ramaswamy et al., 2010; Wakabayashi et al., 2010; Hrabovszky et al., 2011, 2012; Overgaard et al., 2014). For example, while $90 \%$ of KP-synthesizing neurons in ovariectomized mice expressed Tac2 mRNA signal and virtually all contained $T a c 3 r$ signal, estradiol replacement decreased the incidence of 
$\mathrm{NKB} /$ Kiss 1 co-labeled neurons to $53 \%$ and massively suppressed Tac3r mRNA expression (Navarro et al., 2009). In males, only half of the Tac2-expressing neurons expressed Kiss1 mRNA, both in orchidectomized and testosterone-treated male mice (Navarro et al., 2011a). Similarly, a prominent group of NKB-only neurons was also detected in the caudal ARC in orchidectomized male, but not in ovariectomized female rats (Overgaard et al., 2014) and fibers single-labeled for NKB were also reported in the median eminence of female rats (True et al., 2011). The sex steroids estradiol (Navarro et al., 2009) and testosterone (Navarro et al., 2011a) regulate negatively Tac2 and Tac3r expression in the ARC, which was proposed to decrease the activity of KNDy neurons by reducing a positive auto-feedback through NKB/NK3R signaling. Unlike in the above colocalization studies from rodents, only $40-60 \%$ of KP neurons co-expressed NKB immunoreactivity and NKB-only cells were not observed in the ARC of neonatally orchidectomized adult male monkeys (Ramaswamy et al., 2010).

While only NK1R and NK3R tachykinin receptors localized anatomically to KNDy neurons (Navarro et al., 2014), electrophysiological studies on male mice established that NKB stimulates the firing frequency of ARC KP neurons via activation of all three tachykinin receptor forms (NK1R, NK2R, NK3R) (De Croft et al., 2013). In contrast, in ovariectomized goats the NK3R receptor form plays the predominant role in the generation of GnRH pulses, with little, if any, contribution by NK1R and NK2R (Yamamura et al., 2015).

\section{Dyn and its receptor KOR}

The Pdyn gene product Dyn is the third KNDy peptide which was first colocalized with KP and NKB in the sheep; 95\% of Dyn-IR cell bodies in ovariectomized and estrogen-treated ewes were also immunopositive for KP (Goodman et al., 2007). The extent of colocalization between KP and Dyn is also over 90\% in the ARC of female mice, regardless of estrogen status (Navarro et al., 2009). ISH studies also revealed KOR mRNA, although only in relatively low subsets of KP neurons in female and male mice (Navarro et al., 2009).

\section{Galanin}

Galanin is co-expressed with KP not only in the RP3V (Porteous et al., 2011; Kallo et al., 2012) but also in the ARC (Kallo et al., 2012) of mice. In ovariectomized females, galanin mRNA was detected in $42.5 \%$, and galanin immunoreactivity in $12.5 \%$, of KP neurons (Kallo et al., 2012).

\section{GABA and glutamate}

ISH data indicate that KNDy neurons use amino acidergic cotransmitters and express vGluT2 and GAD-67 mRNAs (Cravo et al., 2011). Unlike KP cells of the RP3V which are mostly GABAergic (Cravo et al., 2011), the majority of KNDy neurons are glutamatergic (Cravo et al., 2011), in accordance with the IHC detection of vGluT2 in NKB/Dyn neurons of male and female rats (Ciofi et al., 2006).

\section{IMMUNOHISTOCHEMICAL PROFILING OF HUMAN KP NEURONS IN THE INF}

While neurochemical data about the preoptic KP cell population of the human are currently unavailable, a series of recent studies from our laboratory used immunofluorescent multiplelabeling to determine the phenotype of KP neurons in the Inf (Hrabovszky et al., 2010, 2011, 2012, 2013; Molnar et al., 2012; Skrapits et al., 2014). Colocalization experiments were carried out on autopsy samples from men of variable age groups as well as from postmenopausal women where expression is the highest for KISS1 mRNA (Rometo et al., 2007) and KP immunoreactivity (Hrabovszky et al., 2010). Procedures of tissue processing, technical measures to maximize signals and avoid false-positive colocalization results, and details of the confocal analysis were described in the original publications. Here we extended the colocalization experiments to several other neuropeptides in order to obtain a fingerprint of KP co-transmitters/modulators. Samples were used from both men and postmenopausal women, in view that age and sex have strong effects on neuropeptide levels of KP neurons (Hrabovszky et al., 2011; Molnar et al., 2012). For reference to studies and primary antibodies, see Figure 2.

\section{NEUROPEPTIDES PRESENT IN HIGH PERCENTAGES OF HUMAN KP CELLS \\ Neurokinin B (NKB)}

Similarly to the ARC of laboratory animals, the Inf encloses a large population of KP neurons that also synthesizes NKB (Hrabovszky et al., 2010). The density of KP-IR (and NKB-IR) neurons in the Inf as well as the extent of their co-expression were found to be highly sex-dependent (Hrabovszky et al., 2011) (Figures 1A,B) and age-dependent (Molnar et al., 2012). As reviewed recently (Hrabovszky, 2013), the overall incidences of KP-IR and NKBIR cell bodies are highest in postmenopausal women, lower in aged men and the lowest in young men. The percentage of KP perikarya containing NKB is similar in postmenopausal women ( $71 \%)$, aged men ( $>50$ years; $78 \%)$ and young men $(<50$ years; $73 \%$ ), whereas the percentages of NKB-IR perikarya with KP are highest in postmenopausal women (84\%; Figure 1A), somewhat lower in aged men $(68 \%$; Figure $1 B$ ) and quite low in young men (36\%), indicating that KP expression in NKB neurons is highly sex- and age-dependent. While KP expression might be suppressed in NKB neurons by testosterone in young men, it starts to increase with the decline of this negative feedback in aged individuals. The highest KP level and colocalization percentage are found in postmenopausal women where the inhibitory effect of estradiol is absent. Of note, considerable subsets of the KP-IR and NKB-IR fibers in all models are single-labeled (Hrabovszky et al., 2011; Molnar et al., 2012; Skrapits et al., 2014) and only 8-10\% of KP-IR and NKB-IR axons forming appositions to GnRH neurons in young men and $25-30 \%$ in postmenopausal women contained both KP and NKB (Hrabovszky et al., 2011; Molnar et al., 2012).

\section{Substance $P(S P)$}

The tachykinin peptide SP is derived from the TAC1 gene and acts mainly via the NK1R. ISH studies by Rance et al. revealed that the TAC1 and TAC3 transcripts exhibit overlapping distribution in the Inf and both mRNAs increase remarkably after menopause (Rance and Young, 1991). Our laboratory used immunohistochemistry to analyze SP-IR neurons in the infundibular region (Hrabovszky et al., 2013). These studies demonstrated that the number and the staining intensity of SP-IR perikarya are 

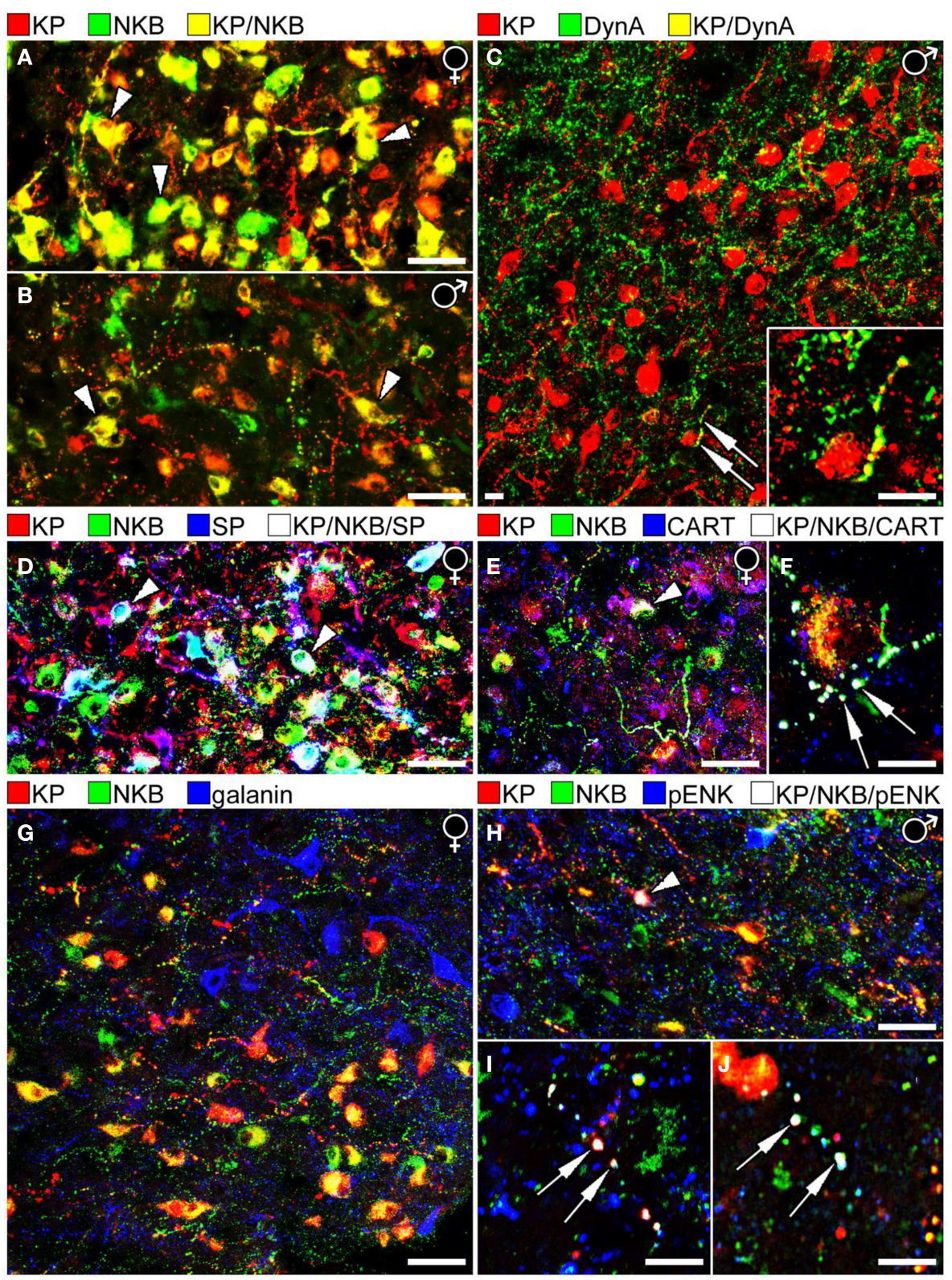

FIGURE 1 | Results of immunofluorescent studies to characterize the neuropeptide phenotype of human KP neurons in the Inf. $(A, B)$ The

highest numbers of KP and NKB neurons and colocalization percentages can be observed in the Inf of postmenopausal women (A). Compare to the weaker labeling of the Inf from a 67 year-old men in (B). Note that the Inf contains many single-labeled axons (red and green), in addition to dual-labeled ones (yellow) in both sexes. (C) Unlike KP neurons of laboratory animals, the majority of human KP neurons do not contain Dyn A immunoreactivity. A rare case of dual-labeled KP/Dyn A axon (arrows) is shown at higher power in the inset. (D) KP neurons often contain SP immunoreactivity in postmenopausal women. White cells labeled by arrowheads correspond to KP/NKB/SP triple-phenotype neurons (Hrabovszky et al., 2013). (E,F) Similarly, CART is co-expressed in large subsets of KP and NKB neurons in postmenopausa women (Skrapits et al., 2014). Arrowhead in (E) and the two arrows in (F) point to a triple-labeled perikaryon and two axon varicosities, respectively. (G) The majority of neuropeptides tested in this study (see Figure 2), including galanin (blue), showed no colocalization with KP or NKB. (H-J) One exception was pENK which occurred in subsets of NKB-IR and KP-IR perikarya and fibers. Arrowhead in (H) points to a perikaryon, whereas arrows in $\mathbf{( I , J ) ~ l a b e l ~}$ axon varicosities that exhibit triple-neuropeptide phenotype (KP/NKB/pENK) The results shown in $\mathbf{( H , I ) ~ v s . ~} \mathbf{( J )}$ were obtained with two different pENK antibodies (see text) to serve as positive control. (Note that the original color of the fluorochromes was changed so that KP is illustrated consistently in red). Scale bars: $40 \mu \mathrm{m}$ in $(\mathbf{A}, \mathbf{B}, \mathbf{D}, \mathbf{E}, \mathbf{G}, \mathbf{H})$ and $12 \mu \mathrm{m}$ in $(\mathbf{C}, \mathbf{F}, \mathbf{I}, \mathbf{J})$. significantly higher in postmenopausal women vs. age-matched men (Hrabovszky et al., 2013). We have shown a considerable overlap in the distribution of SP-IR, NKB-IR and KP-IR perikarya of postmenopausal women and we have established that SP immunoreactivity is present in large subsets of the KP-IR and NKB-IR neurons (Figure 1D); $31 \%$ of KP-IR and $25 \%$ of NKB-IR perikarya in this study contained SP, whereas $16.5 \%$ of all labeled cell bodies exhibited triple-neuropeptide phenotype. Dual- and 


\begin{tabular}{|c|c|c|c|}
\hline \multirow{3}{*}{$\begin{array}{l}\text { Co-transmitters } \\
\text { in KP neurons }\end{array}$} & \multirow[t]{3}{*}{ Laboratory animal data } & \multirow[t]{3}{*}{$\begin{array}{l}\text { Human immunofluorescence } \\
\text { data (Inf only) }\end{array}$} & \multirow{2}{*}{$\begin{array}{c}\begin{array}{c}\text { Neuropeptide antibodies used in human } \\
\text { studies }\end{array} \\
\begin{array}{c}\text { sheep anti-human KP-54 (GQ2) } \\
\text { (Dhillo et al., 2005) }\end{array}\end{array}$} \\
\hline & & & \\
\hline & & & $\begin{array}{l}\text { rabbit anti-human preproKP } \\
\text { (AAS26420C; Antibody verify) }\end{array}$ \\
\hline \multicolumn{4}{|l|}{ KNDy peptides } \\
\hline \multirow{2}{*}{ Dyn } & \multirow{2}{*}{$\begin{array}{l}\text { Reported in the ARC of sheep (Goodman et } \\
\text { al., 2007), mouse (Navarro et al., 2009, } \\
\text { 2011a), rat (Overgaard et al., 2014), } \\
\text { hamster (Bartzen-Sprauer et al., 2014) } \\
\text { and goat (Wakabayashi et al., 2010) }\end{array}$} & \multirow{2}{*}{$\begin{array}{l}\text { Extremely scarce colocalization } \\
\text { in fibers in young men } \\
\text { (Hrabovszky et al., 2012) }\end{array}$} & $\begin{array}{l}\text { rabbit anti-porcine/human Dyn A } \\
\text { (T-4268; Peninsula Laboratories) }\end{array}$ \\
\hline & & & $\begin{array}{l}\text { rabbit anti-Dyn B (IS-35) } \\
\text { (Ciofi et al., 2006) }\end{array}$ \\
\hline \multirow{2}{*}{ NKB } & \multirow{2}{*}{$\begin{array}{l}\text { Reported in the ARC of sheep (Goodman et } \\
\text { al., 2007), mouse (Navarro et al., 2009, } \\
\text { 2011a), rat (Overgaard et al., 2014), } \\
\text { hamster (Bartzen-Sprauer et al., 2014) } \\
\text { and goat (Wakabayashi et al., 2010) } \\
\text { and monkey (Ramaswamy et al., 2010) }\end{array}$} & \multirow{2}{*}{$\begin{array}{l}\text { Present in large subsets } \\
\text { of KP neurons and fibers } \\
\text { (Hrabovszky, 2013; } \\
\text { Hrabovszky et al., 2010,2011; } \\
\text { Molnar et al., 2012) }\end{array}$} & $\begin{array}{c}\text { rabbit anti-human proNKB (IS-681; IS-682) } \\
\text { (Hrabovszky et al., 2010) }\end{array}$ \\
\hline & & & $\begin{array}{l}\text { mouse anti-human Tachykinin-3 } \\
\text { (M-871-100; Biosensis Pty. Ltd) }\end{array}$ \\
\hline \multicolumn{4}{|l|}{ Other neuropeptides } \\
\hline AGRP & $\begin{array}{l}\text { Not detected in the ARC of sheep } \\
\text { (Goodman et al., 2007) }\end{array}$ & $\begin{array}{l}\text { No colocalization } \\
\text { in KP and NKB neurons } \\
\text { (present study) }\end{array}$ & $\begin{array}{l}\text { guinea pig anti-AGRP } \\
\text { (GP-029-50; Biosensis Pty. Ltd) }\end{array}$ \\
\hline$\underset{\text { (POMC) }}{\alpha \text { MSH, } \gamma \text { MSH }}$ & $\begin{array}{l}\text { Not detected in the ARC of } \\
\text { mouse (Cravo et al., 2011) } \\
\text { and sheep (Goodman et al., 2007) }\end{array}$ & $\begin{array}{l}\text { No colocalization } \\
\text { in KP and NKB neurons } \\
\text { (present study) }\end{array}$ & $\begin{array}{l}\text { sheep anti- } \alpha \text { MSH } \\
\text { gift from J. Tatro } \\
\text { (Elias et al., 1998) }\end{array}$ \\
\hline \multirow{2}{*}{ CART } & \multirow{2}{*}{ Not reported } & \multirow{2}{*}{$\begin{array}{l}\text { Colocalized in large subsets } \\
\text { of KP and NKB neurons } \\
\text { (Skrapits et al., 2014) }\end{array}$} & $\begin{array}{l}\text { mouse anti-CART } \\
\text { gift from J.S. Clausen } \\
(\text { Vrang et al., 1999) }\end{array}$ \\
\hline & & & $\begin{array}{l}\text { rabbit anti-CART } \\
\text { gift from M.J. Kuhar } \\
\text { (Koylu et al., 1997) }\end{array}$ \\
\hline CCK & $\begin{array}{l}\text { Not detected in the RP3V of mouse } \\
\text { (Porteous et al., 2011) }\end{array}$ & $\begin{array}{l}\text { No colocalization } \\
\text { in KP and NKB neurons } \\
\text { (present study) }\end{array}$ & $\begin{array}{l}\text { rabbit anti-CCK (IS-15/8) } \\
\text { (Ciofi and Tramu, 1990) }\end{array}$ \\
\hline GAL & $\begin{array}{l}\text { Reported in both the RP3V and the ARC of } \\
\text { mouse (Porteous et al., 2011; } \\
\text { Kallo et al., 2012) }\end{array}$ & $\begin{array}{l}\text { No colocalization } \\
\text { in KP and NKB neurons } \\
\text { (present study) }\end{array}$ & $\begin{array}{l}\text { goat anti-galanin } \\
\text { (EB09679; Everest Biotech Ltd) }\end{array}$ \\
\hline \multirow{2}{*}{ mENK, pENK } & \multirow{2}{*}{$\begin{array}{l}\text { Reported in the RP3V of mouse } \\
\text { (Porteous et al., 2011) }\end{array}$} & \multirow{2}{*}{$\begin{array}{l}\text { Detected in small subsets } \\
\text { of KP-IR and NKB-IR neurons } \\
\text { (present study) }\end{array}$} & $\begin{array}{c}\text { goat anti-human pENK } \\
\text { (EB08195; Everest Biotech Ltd) }\end{array}$ \\
\hline & & & $\begin{array}{l}\text { rabbit anti-mENK (IS-30) } \\
\text { (Magoul et al., 1993; } \\
\text { Covenas et al., 2004) }\end{array}$ \\
\hline NPY & $\begin{array}{l}\text { Not detected in the ARC of mouse } \\
\text { (Cravo et al., 2011) }\end{array}$ & $\begin{array}{l}\text { No colocalization } \\
\text { in KP and NKB neurons } \\
\text { (present study) }\end{array}$ & $\begin{array}{l}\text { sheep anti-NPY (FJL no.14/3A) } \\
\text { gift from I. Merchenthaler } \\
\text { (Wittmann et al., 2002) }\end{array}$ \\
\hline NT & $\begin{array}{l}\text { Not detected in the RP3V of mouse } \\
\text { (Porteous et al., 2011) }\end{array}$ & $\begin{array}{l}\text { No colocalization } \\
\text { in KP and NKB neurons } \\
\text { (present study) }\end{array}$ & $\begin{array}{l}\text { rat anti-NT (IS-RNT) } \\
\text { (Porteous et al., 2011) }\end{array}$ \\
\hline \multirow{2}{*}{ SP } & \multirow{2}{*}{ Not reported } & \multirow{2}{*}{$\begin{array}{l}\text { Colocalized in large subsets } \\
\text { of KP and NKB neurons } \\
\text { (Hrabovszky et al., 2013) }\end{array}$} & $\begin{array}{c}\text { rat anti-SP } \\
(8450-0505 ; \mathrm{AbD} \text { Serotec })\end{array}$ \\
\hline & & & $\begin{array}{l}\text { rabbit anti-SP (505D3) } \\
\text { gift from P. Petrusz } \\
\text { (Conti et al., 1992) }\end{array}$ \\
\hline SS & Not reported & $\begin{array}{l}\text { No colocalization } \\
\text { in KP and NKB neurons } \\
\text { (present study) }\end{array}$ & $\begin{array}{l}\text { guinea pig anti-SS (IS-7/51) } \\
\text { (Ciofi et al., 2006) }\end{array}$ \\
\hline \multicolumn{4}{|l|}{ Neurotransmitters } \\
\hline TH & $\begin{array}{l}\text { Reported in the RP3V of mouse } \\
\text { (Clarkson and Herbison, 2011) } \\
\text { and rat (Kauffman et al., 2007) }\end{array}$ & $\begin{array}{l}\text { No colocalization } \\
\text { in KP and NKB neurons } \\
\text { (present study) }\end{array}$ & $\begin{array}{c}\text { chicken anti-TH } \\
\text { (TYH; Aves Laboratories) }\end{array}$ \\
\hline GAD-67 & $\begin{array}{l}\text { Reported in both the AVPV and } \\
\text { the ARC of mouse (ISH) } \\
\text { (Cravo et al., 2011) }\end{array}$ & Not studied & - \\
\hline vGluT2 & $\begin{array}{l}\text { Reported in both the AVPV and } \\
\text { the ARC of mouse (ISH) (Cravo et al., 2011) } \\
\text { and in the ARC of rat (Ciofi et al., 2006) }\end{array}$ & Not studied & - \\
\hline
\end{tabular}

FIGURE 2 | Summary of neuropeptide/neurotransmitter co-expression data in KP neurons of laboratory animals and the human. AGRP, agouti-related protein; $\alpha \mathrm{MSH}, \alpha$-melanocyte stimulating hormone; ARC, arcuate nucleus; AVPV, anterior periventricular nucleus; CART, cocaineand amphetamine regulated transcript; CCK, cholecystokinin; Dyn, dynorphin; GAD-67, glutamic acid decarboxylase-67; GAL, galanin; Inf, infundibular nucleus; ISH, in situ hybridization; KP, kisspeptin; mENK, met-enkephalin; NKB, neurokinin $B$; NPY, neuropeptide $Y$; NT, neurotensin; $\mathrm{pENK}$, proenkephalin; POMC, proopiomelanocortin; RP3V, rostral periventricular area of the third ventricle; SP, substance $P ; S S$, somatostatin; $\mathrm{TH}$, tyrosine hydroxylase; vGluT2, type-2 vesicular glutamate transporter. 
triple-labeled fibers were also detectable in the infundibular stalk, raising the possibility of that these peptides are co-released into the portal circulation. Moreover, some of these axons established occasional contacts with hypophysiotropic GnRH-IR fibers in the postinfundibular eminence, the infundibular stalk and the neurohypophysis (Hrabovszky et al., 2013; Borsay et al., 2014). These anatomical observations suggest that SP may modulate the secretion of KP and NKB via autocrine/paracrine mechanisms and/or act on hypophysiotropic $\mathrm{GnRH}$ axons to regulate $\mathrm{GnRH}$ release directly.

\section{Cocaine- and amphetamine-regulated transcript (CART)}

CART has been implicated in the regulation of metabolic and neuroendocrine processes including reproduction (Rogge et al., 2008; Smith et al., 2010). In rodents, CART-IR fibers form close contacts with GnRH and KP neurons (Leslie et al., 2001; Rondini et al., 2004; True et al., 2013). Both KP and GnRH neurons respond to CART with depolarization. These data suggest that CART influences GnRH neuronal functions directly as well as indirectly, via modulating $\mathrm{KP} / \mathrm{KISS} 1 \mathrm{R}$-signaling to $\mathrm{GnRH}$ cells (Roa and Herbison, 2012; True et al., 2013).

Colocalization studies of histological specimens from postmenopausal women provided evidence that KP-IR and NKB-IR perikarya often exhibit CART immunoreactivity (Skrapits et al., 2014); $48 \%$ of KP-IR and $30 \%$ of NKB-IR cell bodies were also CART-IR and $24 \%$ of labeled perikarya contained all three signals (Figure 1E). The colocalization phenomena were also detected at the level of fiber varicosities; $17 \%$ of KP-IR and $6 \%$ of NKB-IR fiber varicosities exhibited CART signal and 5\% of all encountered varicosities were triple-labeled (Skrapits et al., 2014) (Figure 1F). Finally, some CART-containing KP and NKB fibers were also immunopositive for SP, indicating the overlap between the CART-IR and the SP-IR populations of KP and NKB neurons (Skrapits et al., 2014).

\section{NEUROPEPTIDES DETECTED AT LOW LEVELS IN HUMAN KP CELLS Dynorphin (Dyn)}

In ISH studies, Dyn expressing cells show a similar postmenopausal hypertrophy as do KP and NKB neurons in the Inf (Rometo and Rance, 2008). However, unlike in rodents and sheep where Dyn was detected in the vast majority of ARC KP cells, morphological studies from our laboratory only found poor evidence for the presence of Dyn immunoreactivity in KP neurons of young men (Hrabovszky et al., 2012) (Figure 1C). Here we have replicated these IHC colocalization experiments on histological samples obtained from postmenopausal women. These new studies were unable to reveal significant amounts of Dyn signal in KP-IR neurons or their processes, although scattered dual-labeled fibers were clearly detectable.

\section{Proenkephalin (pENK)/met-enkephalin (mENK)}

As part of an immunofluorescent screening for additional neuropeptides in human $\mathrm{KP}$ cells, we have addressed the putative colocalization between $\mathrm{pENK}$ and KP. To simultaneously visualize $\mathrm{KP}, \mathrm{NKB}$, and pENK with triple-labeling, a rabbit KP antiserum (Antibody Verify, Las Vegas, NV USA; AAS26420C; 1:1000), a mouse monoclonal NKB antibody (Biosensis Pty. Ltd, Thebarton, SA Australia; M-871-100; 1:3000) and an affinity-purified goat
pENK antibody (Everest Biotech Ltd, Ramona CA USA; EB08195; 1:1000) were used. Tissue processing and IHC procedures were adapted from similar studies (Hrabovszky et al., 2010, 2011, 2012, 2013; Molnar et al., 2012; Skrapits et al., 2014).

While the confocal analysis provided no evidence for $\mathrm{pENK}$ expression in $\mathrm{KP}$ and $\mathrm{NKB}$ neurons of postmenopausal women $(n=3)$ being in line with a previous observation made in mice (Porteous et al., 2011), small subsets of KP-IR and NKB-IR neurons co-expressed pENK immunoreactivity (Figures $\mathbf{1 H}, \mathbf{I}$ ) in histological samples of human males $(n=3$; age: 51,64 , and 78 years). The analysis of $212 \mathrm{KP}$ and/or NKB perikarya established the presence of pENK signal in $12.5 \pm 5.1 \%$ of NKB-IR and 1.9 $\pm 1.0 \%$ of KP-IR neurons. Co-expression was also studied in 700 axon varicosities with an approach adapted from our recent study (Skrapits et al., 2014). pENK signal was contained in $5.7 \pm 2.5 \%$ of NKB-IR and $4.9 \pm 1.8 \%$ of KP-IR axon varicosities. To confirm this colocalization phenomenon, the immunofluorescent detection of pENK in KP neurons has been replicated with a polyclonal rabbit mENK antiserum (IS-30; 1:1000) (Magoul et al., 1993), used in combination with a sheep polyclonal KP antibody (GQ2; 1:1000) (Dhillo et al., 2005) for dual-labeling (Figure 1J).

\section{NEUROPEPTIDES STUDIED BUT NOT DETECTED IN HUMAN KP CELLS}

The neurochemical phenotype of KP and NKB neurons was addressed in a large series of IHC experiments using antibodies against further neuropeptide targets. These colocalization studies failed to reveal galanin in human $\mathrm{KP}$ and $\mathrm{NKB}$ neurons (Figure 1G). This observation reveals a species difference from mice whose KNDy neurons express galanin mRNA and immunoreactivity (Kallo et al., 2012). In line with previous observations made in mice or sheep (Goodman et al., 2007; Cravo et al., 2011; Porteous et al., 2011), agouti-related protein, neuropeptide Y, $\alpha$-melanocyte-stimulating hormone, neurotensin and cholecystokinin were not detectable in human KP and NKB neurons and these neurons were also immunonegative for somatostatin. Finally, human KP and NKB cells did not contain the dopaminergic marker tyrosine hydroxylase which was colocalized earlier with KP in the RP3V of rodents (Kauffman et al., 2007; Clarkson and Herbison, 2011).

\section{CONCLUSIONS}

The functional significance of neuropeptide co-transmitters in $\mathrm{KP}$ neurons may vary largely. So far, NKB has been the most consistently detected co-transmitter of $\mathrm{KP}$ in the mediobasal hypothalamus, independently of species. Its critical involvement in the regulation of human reproduction is well established by the hypogonadotropic hypogonadism of the TAC3- or TAC3Rmutant humans (Topaloglu et al., 2009). In recent clinical studies, $\mathrm{NKB} / \mathrm{NK} 3 \mathrm{R}$ signaling was found essential during early sexual development and its importance became attenuated over time in sustaining the normal functioning of the reproductive axis (Gianetti et al., 2010). It is possible that compensatory mechanisms involve SP which is co-expressed in human KP cells (Hrabovszky et al., 2013) and other neurokinin receptors (NK1R, NK2R) that might substitute NK3R in human KP neurons. A second intensely studied neuropeptide, Dyn, is colocalized in the vast majority of KP neurons is rodents, sheep and goats, giving 
rise to the KNDy neuron terminology (Lehman et al., 2010b) and single-neuron models of the $\mathrm{GnRH} / \mathrm{LH}$ pulse generator (Navarro et al., 2009; Ohkura et al., 2009; Wakabayashi et al., 2010). Somewhat surprisingly, our IHC studies did not reveal significant Dyn expression in KP neurons of young men (Hrabovszky et al., 2012) or postmenopausal women (present study). The low level of colocalization challenges the universal importance of endogenous Dyn in the regulation of episodic GnRH/LH secretion by KP neurons. The possibility exists that $\mathrm{pENK} / \mathrm{mENK}$ we detected in human KP cells replaces some of the functions that Dyn plays in KP cells of laboratory species. The detection of SP, CART and pENK/mENK in KP neurons of the human which was not reported earlier in laboratory species indicates that humans and laboratory animals may use considerably different neuropeptide signaling mechanisms to regulate sex steroid feedback and the GnRH neurosecretory pulses. Finally, a large set of neuropeptides we have tested in this study for co-expression with KP do not seem to be present in KP neurons of any species studied so far. This peptide group includes neurotensin, cholecystokinin, proopiomelanocortin-derivatives, agouti-related protein, neuropeptide $\mathrm{Y}$ and somatostatin. Information about the neurochemical phenotype of human KP neurons summarized in this minireview will help us understand the peptidergic regulatory mechanisms of sex steroid feedback and episodic GnRH/LH secretion.

\section{AUTHOR CONTRIBUTIONS}

Katalin Skrapits, Philippe Ciofi, Zsolt Liposits and Erik Hrabovszky conceived and designed the experiments and wrote the paper. Beáta Á. Borsay and László Herczeg contributed essential research material.

\section{ACKNOWLEDGMENTS}

The research leading to these results received funding from the National Science Foundation of Hungary (OTKA K83710, K112669, K100722), the National Development Agency (BONUS HU 08/2-2011-0006) and the Seventh Framework Programme of the European Community (FP7/2007-2013) under grant agreement No. 245009.

\section{REFERENCES}

Adachi, S., Yamada, S., Takatsu, Y., Matsui, H., Kinoshita, M., Takase, K., et al. (2007). Involvement of anteroventral periventricular metastin/kisspeptin neurons in estrogen positive feedback action on luteinizing hormone release in female rats. J. Reprod. Dev. 53, 367-378. doi: 10.1262/jrd.18146

Amstalden, M., Coolen, L. M., Hemmerle, A. M., Billings, H. J., Connors, J. M., Goodman, R. L., et al. (2010). Neurokinin 3 receptor immunoreactivity in the septal region, preoptic area and hypothalamus of the female sheep: colocalisation in neurokinin B cells of the arcuate nucleus but not in gonadotrophin-releasing hormone neurones. J. Neuroendocrinol. 22, 1-12. doi: 10.1111/j.1365-2826.2009.01930.x

Bartzen-Sprauer, J., Klosen, P., Ciofi, P., Mikkelsen, J. D., and Simonneaux, V. (2014). Photoperiodic co-regulation of kisseptin, neurokinin B and dynorphin in the hypothalamus of a seasonal rodent. J. Neuroendocrinol. 26, 510-520. doi: $10.1111 /$ jne. 12171

Borsay, B. A., Skrapits, K., Herczeg, L., Ciofi, P., Bloom, S. R., Ghatei, M. A., et al. (2014). Hypophysiotropic gonadotropin-releasing hormone projections are exposed to dense plexuses of kisspeptin, neurokinin B and substance $p$ immunoreactive fibers in the human: a study on tissues from postmenopausal women. Neuroendocrinology 100, 141-152. doi: 10.1159/000368362
Burke, M. C., Letts, P. A., Krajewski, S. J., and Rance, N. E. (2006). Coexpression of dynorphin and neurokinin B immunoreactivity in the rat hypothalamus: Morphologic evidence of interrelated function within the arcuate nucleus. J. Comp. Neurol. 498, 712-726. doi: 10.1002/cne.21086

Cheng, G., Coolen, L. M., Padmanabhan, V., Goodman, R. L., and Lehman, M. N. (2010). The kisspeptin/neurokinin B/dynorphin (KNDy) cell population of the arcuate nucleus: sex differences and effects of prenatal testosterone in sheep. Endocrinology 151, 301-311. doi: 10.1210/en.2009-0541

Ciofi, P., Leroy, D., and Tramu, G. (2006). Sexual dimorphism in the organization of the rat hypothalamic infundibular area. Neuroscience 141, 1731-1745. doi: 10.1016/j.neuroscience.2006.05.041

Ciofi, P., and Tramu, G. (1990). Distribution of cholecystokinin-likeimmunoreactive neurons in the guinea pig forebrain. J. Comp. Neurol. 300, 82-112. doi: 10.1002/cne.903000107

Clarkson, J., D’anglemont De Tassigny, X., Moreno, A. S., Colledge, W. H., and Herbison, A. E. (2008). Kisspeptin-GPR54 signaling is essential for preovulatory gonadotropin-releasing hormone neuron activation and the luteinizing hormone surge. J. Neurosci. 28, 8691-8697. doi: 10.1523/JNEUROSCI.177508.2008

Clarkson, J., and Herbison, A. E. (2006). Postnatal development of kisspeptin neurons in mouse hypothalamus; sexual dimorphism and projections to gonadotropin-releasing hormone neurons. Endocrinology 147, 5817-5825. doi: 10.1210/en.2006-0787

Clarkson, J., and Herbison, A. E. (2011). Dual phenotype kisspeptin-dopamine neurones of the rostral periventricular area of the third ventricle project to gonadotrophin-releasing hormone neurones. J. Neuroendocrinol. 23, 293-301. doi: 10.1111/j.1365-2826.2011.02107.x

Conti, F., De Biasi, S., Fabri, M., Abdullah, L., Manzoni, T., and Petrusz, P. (1992). Substance P-containing pyramidal neurons in the cat somatic sensory cortex. J. Comp. Neurol. 322, 136-148. doi: 10.1002/cne.903220111

Covenas, R., Martin, F., Salinas, P., Rivada, E., Smith, V., Aguilar, L. A., et al. (2004). An immunocytochemical mapping of methionine-enkephalin-Arg(6)Gly(7)-Leu(8) in the human brainstem. Neuroscience 128, 843-859. doi: 10.1016/j.neuroscience.2004.07.009

Cravo, R. M., Margatho, L. O., Osborne-Lawrence, S., Donato, J. Jr., Atkin, S., Bookout, A. L., et al. (2011). Characterization of Kiss1 neurons using transgenic mouse models. Neuroscience 173, 37-56. doi: 10.1016/j.neuroscience.2010.11.022

D’anglemont De Tassigny, X., Fagg, L. A., Dixon, J. P., Day, K., Leitch, H. G., Hendrick, A. G., et al. (2007). Hypogonadotropic hypogonadism in mice lacking a functional Kiss1 gene. Proc. Natl. Acad. Sci. U.S.A. 104, 10714-10719. doi: 10.1073/pnas.0704114104

De Croft, S., Boehm, U., and Herbison, A. E. (2013). Neurokinin B activates arcuate kisspeptin neurons through multiple tachykinin receptors in the male mouse. Endocrinology 154, 2750-2760. doi: 10.1210/en.2013-1231

De Roux, N., Genin, E., Carel, J. C., Matsuda, F., Chaussain, J. L., and Milgrom, E. (2003). Hypogonadotropic hypogonadism due to loss of function of the KiSS1derived peptide receptor GPR54. Proc. Natl. Acad. Sci. U.S.A. 100, 10972-10976. doi: $10.1073 /$ pnas. 1834399100

Dhillo, W. S., Chaudhri, O. B., Patterson, M., Thompson, E. L., Murphy, K. G., Badman, M. K., et al. (2005). Kisspeptin-54 stimulates the hypothalamicpituitary gonadal axis in human males. J. Clin. Endocrinol. Metab. 90, 6609-6615. doi: 10.1210/jc.2005-1468

Dumalska, I., Wu, M., Morozova, E., Liu, R., Van Den Pol, A., and Alreja, M. (2008). Excitatory effects of the puberty-initiating peptide kisspeptin and group I metabotropic glutamate receptor agonists differentiate two distinct subpopulations of gonadotropin-releasing hormone neurons. J. Neurosci. 28, 8003-8013. doi: 10.1523/JNEUROSCI.1225-08.2008

Elias, C. F., Saper, C. B., Maratos-Flier, E., Tritos, N. A., Lee, C., Kelly, J., et al. (1998). Chemically defined projections linking the mediobasal hypothalamus and the lateral hypothalamic area. J. Comp. Neurol. 402, 442-459.

Foradori, C. D., Amstalden, M., Goodman, R. L., and Lehman, M. N. (2006). Colocalisation of dynorphin a and neurokinin B immunoreactivity in the arcuate nucleus and median eminence of the sheep. J. Neuroendocrinol. 18, 534-541. doi: 10.1111/j.1365-2826.2006.01445.x

Funes, S., Hedrick, J. A., Vassileva, G., Markowitz, L., Abbondanzo, S., Golovko, A., et al. (2003). The KiSS-1 receptor GPR54 is essential for the development of the murine reproductive system. Biochem. Biophys. Res. Commun. 312, 1357-1363. doi: 10.1016/j.bbrc.2003.11.066 
Gianetti, E., Tusset, C., Noel, S. D., Au, M. G., Dwyer, A. A., Hughes, V. A., et al. (2010). TAC3/TACR3 mutations reveal preferential activation of gonadotropinreleasing hormone release by neurokinin B in neonatal life followed by reversal in adulthood. J. Clin. Endocrinol. Metab. 95, 2857-2867. doi: 10.1210/jc.20092320

Goodman, R. L., Lehman, M. N., Smith, J. T., Coolen, L. M., De Oliveira, C. V., Jafarzadehshirazi, M. R., et al. (2007). Kisspeptin neurons in the arcuate nucleus of the ewe express both dynorphin A and neurokinin B. Endocrinology 148, 5752-5760. doi: 10.1210/en.2007-0961

Gottsch, M. L., Cunningham, M. J., Smith, J. T., Popa, S. M., Acohido, B. V., Crowley, W. F., et al. (2004). A role for kisspeptins in the regulation of gonadotropin secretion in the mouse. Endocrinology 145, 4073-4077. doi: 10.1210/en.2004-0431

Guran, T., Tolhurst, G., Bereket, A., Rocha, N., Porter, K., Turan, S., et al. (2009). Hypogonadotropic hypogonadism due to a novel missense mutation in the first extracellular loop of the neurokinin B receptor. J. Clin. Endocrinol. Metab. 94, 3633-3639. doi: 10.1210/jc.2009-0551

Han, S. K., Gottsch, M. L., Lee, K. J., Popa, S. M., Smith, J. T., Jakawich, S. K., et al. (2005). Activation of gonadotropin-releasing hormone neurons by kisspeptin as a neuroendocrine switch for the onset of puberty. J. Neurosci. 25, 11349-11356. doi: 10.1523/JNEUROSCI.3328-05.2005

Herbison, A. E. (2008). Estrogen positive feedback to gonadotropin-releasing hormone $(\mathrm{GnRH})$ neurons in the rodent: the case for the rostral periventricular area of the third ventricle (RP3V). Brain Res. Rev. 57, 277-287. doi: 10.1016/j.brainresrev.2007.05.006

Hrabovszky, E. (2013). Neuroanatomy of the human hypothalamic kisspeptin system. Neuroendocrinology 99, 33-48. doi: 10.1159/000356903

Hrabovszky, E., Borsay, B. A., Rácz, K., Herczeg, L., Ciofi, P., Bloom, S. R., et al. (2013). Substance P immunoreactivity exhibits frequent colocalization with kisspeptin and neurokinin $\mathrm{B}$ in the human infundibular region. PLoS ONE 8:e72369. doi: 10.1371/journal.pone.0072369

Hrabovszky, E., Ciofi, P., Vida, B., Horvath, M. C., Keller, E., Caraty, A., et al. (2010). The kisspeptin system of the human hypothalamus: sexual dimorphism and relationship with gonadotropin-releasing hormone and neurokinin B neurons. Eur. J. Neurosci. 31, 1984-1998. doi: 10.1111/j.1460-9568.2010.07239.x

Hrabovszky, E., Molnar, C. S., Sipos, M. T., Vida, B., Ciofi, P., Borsay, B. A., et al. (2011). Sexual dimorphism of kisspeptin and neurokinin B immunoreactive neurons in the infundibular nucleus of aged men and women. Front. Endocrinol. 2:80. doi: 10.3389/fendo.2011.00080

Hrabovszky, E., Sipos, M. T., Molnar, C. S., Ciofi, P., Borsay, B. A., Gergely, P., et al. (2012). Low degree of overlap between kisspeptin, neurokinin B, and dynorphin immunoreactivities in the infundibular nucleus of young male human subjects challenges the KNDy neuron concept. Endocrinology 153, 4978-4989. doi: 10.1210/en.2012-1545

Irwig, M. S., Fraley, G. S., Smith, J. T., Acohido, B. V., Popa, S. M., Cunningham, M. J., et al. (2004). Kisspeptin activation of gonadotropin releasing hormone neurons and regulation of KiSS-1 mRNA in the male rat. Neuroendocrinology 80, 264-272. doi: 10.1159/000083140

Kallo, I., Vida, B., Deli, L., Molnar, C. S., Hrabovszky, E., Caraty, A., et al. (2012). Co-localisation of kisspeptin with galanin or neurokinin $\mathrm{B}$ in afferents to mouse GnRH neurones. J. Neuroendocrinol. 24, 464-476. doi: 10.1111/j.13652826.2011.02262.x

Kauffman, A. S., Gottsch, M. L., Roa, J., Byquist, A. C., Crown, A., Clifton, D. K., et al. (2007). Sexual differentiation of Kiss 1 gene expression in the brain of the rat. Endocrinology 148, 1774-1783. doi: 10.1210/en.2006-1540

Kinoshita, M., Tsukamura, H., Adachi, S., Matsui, H., Uenoyama, Y., Iwata, K., et al. (2005). Involvement of central metastin in the regulation of preovulatory luteinizing hormone surge and estrous cyclicity in female rats. Endocrinology 146, 4431-4436. doi: 10.1210/en.2005-0195

Kirilov, M., Clarkson, J., Liu, X., Roa, J., Campos, P., Porteous, R., et al. (2013). Dependence of fertility on kisspeptin-Gpr54 signaling at the GnRH neuron. Nat. Commun. 4, 2492. doi: 10.1038/ncomms3492

Koylu, E. O., Couceyro, P. R., Lambert, P. D., Ling, N. C., Desouza, E. B., and Kuhar, M. J. (1997). Immunohistochemical localization of novel CART peptides in rat hypothalamus, pituitary and adrenal gland. J. Neuroendocrinol. 9, 823-833. doi: 10.1046/j.1365-2826.1997.00651.x

Krey, L. C., Butler, W. R., and Knobil, E. (1975). Surgical disconnection of the medial basal hypothalamus and pituitary function in the rhesus monkey. I. Gonadotropin secretion. Endocrinology 96, 1073-1087. doi: 10.1210/endo-965-1073
Lapatto, R., Pallais, J. C., Zhang, D., Chan, Y. M., Mahan, A., Cerrato, F., et al. (2007). Kiss1-/- mice exhibit more variable hypogonadism than Gpr54-/- mice. Endocrinology 148, 4927-4936. doi: 10.1210/en.2007-0078

Lasaga, M., and Debeljuk, L. (2011). Tachykinins and the hypothalamopituitary-gonadal axis: an update. Peptides 32, 1972-1978. doi: 10.1016/j.peptides.2011.07.009

Lehman, M. N., Coolen, L. M., and Goodman, R. L. (2010b). Minireview: kisspeptin/neurokinin B/dynorphin (KNDy) cells of the arcuate nucleus: a central node in the control of gonadotropin-releasing hormone secretion. Endocrinology 151, 3479-3489. doi: 10.1210/en.2010-0022

Lehman, M. N., Merkley, C. M., Coolen, L. M., and Goodman, R. L. (2010a). Anatomy of the kisspeptin neural network in mammals. Brain Res. 1364, 90-102. doi: 10.1016/j.brainres.2010.09.020

Leslie, R. A., Sanders, S. J., Anderson, S. I., Schuhler, S., Horan, T. L., and Ebling, F. J. (2001). Appositions between cocaine and amphetamine-related transcript- and gonadotropin releasing hormone-immunoreactive neurons in the hypothalamus of the Siberian hamster. Neurosci. Lett. 314, 111-114. doi: 10.1016/S0304-3940(01)02291-1

Magoul, R., Dubourg, P., Benjelloun, W., and Tramu, G. (1993). Direct and indirect enkephalinergic synaptic inputs to the rat arcuate nucleus studied by combination of retrograde tracing and immunocytochemistry. Neuroscience 55, 1055-1066. doi: 10.1016/0306-4522(93)90319-B

Matsuda, F., Nakatsukasa, K., Suetomi, Y., Naniwa, Y., Ito, D., Inoue, N., et al. (2014). The LH surge-generating system is functional in male goats as in females: involvement of kisspeptin neurones in the medial preoptic area. $J$. Neuroendocrinol. 27, 57-65. doi: 10.1111/jne.12235

Matsui, H., Takatsu, Y., Kumano, S., Matsumoto, H., and Ohtaki, T. (2004). Peripheral administration of metastin induces marked gonadotropin release and ovulation in the rat. Biochem. Biophys. Res. Commun. 320, 383-388. doi: 10.1016/j.bbrc.2004.05.185

Messager, S., Chatzidaki, E. E., Ma, D., Hendrick, A. G., Zahn, D., Dixon, J., et al. (2005). Kisspeptin directly stimulates gonadotropin-releasing hormone release via G protein-coupled receptor 54. Proc. Natl. Acad. Sci. U.S.A. 102, 1761-1766. doi: 10.1073/pnas.0409330102

Mittelman-Smith, M. A., Williams, H., Krajewski-Hall, S. J., Lai, J., Ciofi, P., McMullen, N. T., et al. (2012). Arcuate kisspeptin/neurokinin B/dynorphin (KNDy) neurons mediate the estrogen suppression of gonadotropin secretion and body weight. Endocrinology 153, 2800-2812. doi: 10.1210/en.2012-1045

Molnar, C. S., Vida, B., Sipos, M. T., Ciofi, P., Borsay, B. A., Racz, K., et al. (2012). Morphological evidence for enhanced kisspeptin and neurokinin B signaling in the infundibular nucleus of the aging man. Endocrinology 153, 5428-5439. doi: 10.1210/en.2012-1739

Navarro, V., Bosch, M., Leon, S., Simavli, S., True, C., Pinilla, L., et al. (2014). The integrated hypothalamic tachykinin-kisspeptin system as a central coordinator for reproduction. Endocrinology 156, 627-637. doi: 10.1210/en.2014-1651

Navarro, V. M., Castellano, J. M., Fernandez-Fernandez, R., Tovar, S., Roa, J., Mayen, A., et al. (2005a). Effects of KiSS-1 peptide, the natural ligand of GPR54, on follicle-stimulating hormone secretion in the rat. Endocrinology 146, 1689-1697. doi: 10.1210/en.2004-1353

Navarro, V. M., Castellano, J. M., Fernandez-Fernandez, R., Tovar, S., Roa, J., Mayen, A., et al. (2005b). Characterization of the potent luteinizing hormonereleasing activity of KiSS-1 peptide, the natural ligand of GPR54. Endocrinology 146, 156-163. doi: 10.1210/en.2004-0836

Navarro, V. M., Castellano, J. M., McConkey, S. M., Pineda, R., Ruiz-Pino, F., Pinilla, L., et al. (2011b). Interactions between kisspeptin and neurokinin B in the control of GnRH secretion in the female rat. Am. J. Physiol. Endocrinol. Metab. 300, E202-E210. doi: 10.1152/ajpendo.00517.2010

Navarro, V. M., Gottsch, M. L., Chavkin, C., Okamura, H., Clifton, D. K., and Steiner, R. A. (2009). Regulation of gonadotropin-releasing hormone secretion by kisspeptin/dynorphin/neurokinin B neurons in the arcuate nucleus of the mouse. J. Neurosci. 29, 11859-11866. doi: 10.1523/JNEUROSCI.1569-09.2009

Navarro, V. M., Gottsch, M. L., Wu, M., Garcia-Galiano, D., Hobbs, S. J., Bosch, M. A., et al. (2011a). Regulation of NKB pathways and their roles in the control of Kiss1 neurons in the arcuate nucleus of the male mouse. Endocrinology 152, 4265-4275. doi: 10.1210/en.2011-1143

Novaira, H. J., Sonko, M. L., Hoffman, G., Koo, Y., Ko, C., Wolfe, A., et al. (2014). Disrupted kisspeptin signaling in GnRH neurons leads to hypogonadotrophic hypogonadism. Mol. Endocrinol. 28, 225-238. doi: 10.1210/me.2013-1319

Ohkura, S., Takase, K., Matsuyama, S., Mogi, K., Ichimaru, T., Wakabayashi, Y., et al. (2009). Gonadotrophin-releasing hormone pulse generator activity in the 
hypothalamus of the goat. J. Neuroendocrinol. 21, 813-821. doi: 10.1111/j.13652826.2009.01909.x

Overgaard, A., Ruiz-Pino, F., Castellano, J. M., Tena-Sempere, M., and Mikkelsen, J. D. (2014). Disparate changes in kisspeptin and neurokinin B expression in the arcuate nucleus after sex steroid manipulation reveal differential regulation of the two KNDy peptides in rats. Endocrinology 155, 3945-3955. doi: 10.1210/en.2014-1200

Pielecka-Fortuna, J., Chu, Z., and Moenter, S. M. (2008). Kisspeptin acts directly and indirectly to increase gonadotropin-releasing hormone neuron activity and its effects are modulated by estradiol. Endocrinology 149, 1979-1986. doi: 10.1210/en.2007-1365

Plant, T. M., Moossy, J., Hess, D. L., Nakai, Y., McCormack, J. T., and Knobil, E. (1979). Further studies on the effects of lesions in the rostral hypothalamus on gonadotropin secretion in the female rhesus monkey (Macaca mulatta). Endocrinology 105, 465-473. doi: 10.1210/endo-105-2-465

Porteous, R., Petersen, S. L., Yeo, S. H., Bhattarai, J. P., Ciofi, P., De Tassigny, X. D., et al. (2011). Kisspeptin neurons co-express met-enkephalin and galanin in the rostral periventricular region of the female mouse hypothalamus. J. Comp. Neurol. 519, 3456-3469. doi: 10.1002/cne.22716

Ramaswamy, S., Guerriero, K. A., Gibbs, R. B., and Plant, T. M. (2008). Structural interactions between kisspeptin and GnRH neurons in the mediobasal hypothalamus of the male rhesus monkey (Macaca mulatta) as revealed by double immunofluorescence and confocal microscopy. Endocrinology 149, 4387-4395. doi: 10.1210/en.2008-0438

Ramaswamy, S., Seminara, S. B., Ali, B., Ciofi, P., Amin, N. A., and Plant, T. M. (2010). Neurokinin B stimulates GnRH release in the male monkey (Macaca mulatta) and is colocalized with kisspeptin in the arcuate nucleus. Endocrinology 151, 4494-4503. doi: 10.1210/en.2010-0223

Rance, N. E., Dacks, P. A., Mittelman-Smith, M. A., Romanovsky, A. A., and Krajewski-Hall, S. J. (2013). Modulation of body temperature and LH secretion by hypothalamic KNDy (kisspeptin, neurokinin B and dynorphin) neurons: a novel hypothesis on the mechanism of hot flushes. Front. Neuroendocrinol. 34, 211-227. doi: 10.1016/j.yfrne.2013.07.003

Rance, N. E., and Young, W. S. III. (1991). Hypertrophy and increased gene expression of neurons containing neurokinin-B and substance-P messenger ribonucleic acids in the hypothalami of postmenopausal women. Endocrinology 128, 2239-2247. doi: 10.1210/endo-128-5-2239

Roa, J., and Herbison, A. E. (2012). Direct regulation of GnRH neuron excitability by arcuate nucleus POMC and NPY neuron neuropeptides in female mice. Endocrinology 153, 5587-5599. doi: 10.1210/en.2012-1470

Robertson, J. L., Clifton, D. K., De La Iglesia, H. O., Steiner, R. A., and Kauffman, A. S. (2009). Circadian regulation of Kiss1 neurons: implications for timing the preovulatory gonadotropin-releasing hormone/luteinizing hormone surge. Endocrinology 150, 3664-3671. doi: 10.1210/en.2009-0247

Rogge, G., Jones, D., Hubert, G. W., Lin, Y., and Kuhar, M. J. (2008). CART peptides: regulators of body weight, reward and other functions. Nat. Rev. Neurosci. 9, 747-758. doi: 10.1038/nrn2493

Rometo, A. M., Krajewski, S. J., Voytko, M. L., and Rance, N. E. (2007). Hypertrophy and increased kisspeptin gene expression in the hypothalamic infundibular nucleus of postmenopausal women and ovariectomized monkeys. J. Clin. Endocrinol. Metab. 92, 2744-2750. doi: 10.1210/jc.2007-0553

Rometo, A. M., and Rance, N. E. (2008). Changes in prodynorphin gene expression and neuronal morphology in the hypothalamus of postmenopausal women. J. Neuroendocrinol. 20, 1376-1381. doi: 10.1111/j.1365-2826.2008.01796.x

Rondini, T. A., Baddini, S. P., Sousa, L. F., Bittencourt, J. C., and Elias, C. F. (2004). Hypothalamic cocaine- and amphetamine-regulated transcript neurons project to areas expressing gonadotropin releasing hormone immunoreactivity and to the anteroventral periventricular nucleus in male and female rats. Neuroscience 125, 735-748. doi: 10.1016/j.neuroscience.2003.12.045

Ruka, K. A., Burger, L. L., and Moenter, S. M. (2013). Regulation of arcuate neurons coexpressing kisspeptin, neurokinin $B$, and dynorphin by modulators of neurokinin 3 and kappa-opioid receptors in adult male mice. Endocrinology 154, 2761-2771. doi: 10.1210/en.2013-1268

Seminara, S. B., Messager, S., Chatzidaki, E. E., Thresher, R. R., Acierno, J. S. Jr., Shagoury, J. K., et al. (2003). The GPR54 gene as a regulator of puberty. N. Engl. J. Med. 349, 1614-1627. doi: 10.1056/NEJMoa035322

Shahab, M., Mastronardi, C., Seminara, S. B., Crowley, W. F., Ojeda, S. R., and Plant, T. M. (2005). Increased hypothalamic GPR54 signaling: a potential mechanism for initiation of puberty in primates. Proc. Natl. Acad. Sci. U.S.A. 102, 2129-2134. doi: 10.1073/pnas.0409822102
Skrapits, K., Borsay, B. A., Herczeg, L., Ciofi, P., Bloom, S. R., Ghatei, M. A., et al. (2014). Colocalization of cocaine- and amphetamine-regulated transcript with kisspeptin and neurokinin B in the human infundibular region. PLoS ONE 9:e103977. doi: 10.1371/journal.pone.0103977

Smith, J. T., Coolen, L. M., Kriegsfeld, L. J., Sari, I. P., Jaafarzadehshirazi, M. R., Maltby, M., et al. (2008). Variation in kisspeptin and RFamide-related peptide (RFRP) expression and terminal connections to gonadotropin-releasing hormone neurons in the brain: a novel medium for seasonal breeding in the sheep. Endocrinology 149, 5770-5782. doi: 10.1210/en.2008-0581

Smith, J. T., Li, Q., Pereira, A., and Clarke, I. J. (2009). Kisspeptin neurons in the ovine arcuate nucleus and preoptic area are involved in the preovulatory luteinizing hormone surge. Endocrinology 150, 5530-5538. doi: 10.1210/en.2009-0712

Smith, M. S., True, C., and Grove, K. L. (2010). The neuroendocrine basis of lactation-induced suppression of GnRH: role of kisspeptin and leptin. Brain Res. 1364, 139-152. doi: 10.1016/j.brainres.2010.08.038

Topaloglu, A. K., Reimann, F., Guclu, M., Yalin, A. S., Kotan, L. D., Porter, K. M., et al. (2009). TAC3 and TACR3 mutations in familial hypogonadotropic hypogonadism reveal a key role for Neurokinin B in the central control of reproduction. Nat. Genet. 41, 354-358. doi: 10.1038/ng.306

Topaloglu, A. K., Tello, J. A., Kotan, L. D., Ozbek, M. N., Yilmaz, M. B., Erdogan, S., et al. (2012). Inactivating KISS1 mutation and hypogonadotropic hypogonadism. N. Engl. J. Med. 366, 629-635. doi: 10.1056/NEJMoal1 11184

True, C., Kirigiti, M., Ciofi, P., Grove, K. L., and Smith, M. S. (2011) Characterisation of arcuate nucleus kisspeptin/neurokinin B neuronal projections and regulation during lactation in the rat. J. Neuroendocrinol. 23, 52-64. doi: $10.1111 / j .1365-2826.2010 .02076 . x$

True, C., Verma, S., Grove, K. L., and Smith, M. S. (2013). Cocaine- and amphetamine-regulated transcript is a potent stimulator of GnRH and kisspeptin cells and may contribute to negative energy balance-induced reproductive inhibition in females. Endocrinology 154, 2821-2832. doi: 10.1210/en.2013-1156

Vrang, N., Larsen, P. J., Clausen, J. T., and Kristensen, P. (1999). Neurochemical characterization of hypothalamic cocaine- amphetamine-regulated transcript neurons. J. Neurosci. 19, RC5.

Wakabayashi, Y., Nakada, T., Murata, K., Ohkura, S., Mogi, K., Navarro, V. M., et al. (2010). Neurokinin B and dynorphin A in kisspeptin neurons of the arcuate nucleus participate in generation of periodic oscillation of neural activity driving pulsatile gonadotropin-releasing hormone secretion in the goat. J. Neurosci. 30, 3124-3132. doi: 10.1523/JNEUROSCI.5848-09.2010

Wittmann, G., Liposits, Z., Lechan, R. M., and Fekete, C. (2002). Medullary adrenergic neurons contribute to the neuropeptide Y-ergic innervation of hypophysiotropic thyrotropin-releasing hormone-synthesizing neurons in the rat. Neurosci. Lett. 324, 69-73. doi: 10.1016/S0304-3940(02) 00165-9

Yamamura, T., Wakabayashi, Y., Ohkura, S., Navarro, V. M., and Okamura, H. (2015). Effects of intravenous administration of neurokinin receptor subtype-selective agonists on gonadotropin-releasing hormone pulse generator activity and luteinizing hormone secretion in goats. J. Reprod. Dev. doi: 10.1262/jrd.2014-109. (in press)

Conflict of Interest Statement: The authors declare that the research was conducted in the absence of any commercial or financial relationships that could be construed as a potential conflict of interest.

Received: 14 November 2014; accepted: 21 January 2015; published online: 10 February 2015

Citation: Skrapits K, Borsay BA, Herczeg L, Ciofi P, Liposits $Z$ and Hrabovszky E (2015) Neuropeptide co-expression in hypothalamic kisspeptin neurons of laboratory animals and the human. Front. Neurosci. 9:29. doi: 10.3389/fnins.2015.00029

This article was submitted to Neuroendocrine Science, a section of the journal Frontiers in Neuroscience.

Copyright (๑ 2015 Skrapits, Borsay, Herczeg, Ciofi, Liposits and Hrabovszky. This is an open-access article distributed under the terms of the Creative Commons Attribution License (CC BY). The use, distribution or reproduction in other forums is permitted, provided the original author(s) or licensor are credited and that the original publication in this journal is cited, in accordance with accepted academic practice. No use, distribution or reproduction is permitted which does not comply with these terms. 